\title{
New microsatellite markers for the abalone Haliotis midae developed by 454 pyrosequencing and in silico analyses
}

\author{
R. Slabbert ${ }^{1,2}$, J.-A. Hepple ${ }^{1,2}$, C. Rhode ${ }^{1}$, A.E. Bester-Van der Merwe ${ }^{1}$ \\ and R. Roodt-Wilding ${ }^{1}$ \\ ${ }^{1}$ Molecular Aquatic Research Group, Department of Genetics, \\ Stellenbosch University, Matieland, South Africa \\ ${ }^{2}$ Central Analytical Facilities, Stellenbosch University, Matieland, South Africa \\ Corresponding author: R. Slabbert \\ E-mail: rslabbrt@sun.ac.za
}

Genet. Mol. Res. 11 (3): 2769-2779 (2012)

Received September 2, 2011

Accepted July 10, 2012

Published August 24, 2012

DOI http://dx.doi.org/10.4238/2012.August.24.2

\begin{abstract}
Farming of Haliotis midae is the most lucrative aquaculture venture in South Africa. The genome of this species needs to be studied to assist in selective breeding programs aimed at increasing overall yield, and molecular markers will be required to attain this goal. We identified and characterized 82 polymorphic microsatellite loci by using repeat-enriched genomic libraries and high-throughput pyrosequencing technology. The observed number of alleles ranged from 2 to 21 , expected heterozygosity from 0.063 to 0.968 , observed heterozygosity from 0.000 to 1.000 , and polymorphic information content from 0.059 to 0.934 . Three loci gave significant hits to other haliotid genes and/or microsatellite loci; hits to genes were always located in the $5^{\prime} / 3^{\prime}$-UTR or intron region. Many of these newly designed markers would be useful for parentage, population and linkage studies.
\end{abstract}

Key words: 454 Sequencing; Aquaculture; Bioinformatics; Molecular markers; Haliotis midae 


\section{INTRODUCTION}

Five abalone species live in the waters of South Africa but only one, Haliotis midae, is cultivated and exported. The $H$. midae industry is the most lucrative aquaculture sector in South Africa, with 14 active hatcheries and grow-out facilities (DAFF, 2012). Commercial abalone farming of H. midae was initiated in 1990 (Cook and Britz, 1991), and 15 years later, a genetics research program was introduced as a collaborative effort among academic institutions, industry, and government (Slabbert et al., 2009b). The overall aim of the program is the genetic characterization and enhancement of $H$. midae within its natural and commercial settings. To achieve this aim, various molecular genetic markers are needed to facilitate different aspects of the program such as genetic diversity studies, pedigree reconstructions, linkage mapping, and quantitative trait loci (QTL) discovery.

Microsatellite markers are both extremely popular in modern molecular disciplines and widely used in abalone genetic studies such as population structure and genetic diversity studies, parentage studies, linkage mapping, and QTL mapping (Baranski et al., 2006; Gutiérrez-Gonzales et al., 2007; Li et al., 2007; Slabbert et al., 2009a; Shi et al., 2010). Microsatellite loci have already been isolated for various abalone species, including Haliotis rubra (Evans et al., 2000), H. asinina (Selvamani et al., 2000), and H. discus hannai (Li and Akihiro, 2007). A number of microsatellite markers have also been published as a result of the H. midae genetic research program (Bester et al., 2004; Slabbert et al., 2008, 2010).

The development of microsatellite markers is labor intensive and costly. Genomic libraries must be constructed and enriched for microsatellite repeats, and clones must be screened and then sequenced (Zane et al., 2002). Even more advanced protocols such as fast isolation by amplified fragment length polymorphism (AFLP) of sequences containing repeats (FIASCO; Zane et al., 2002) and the SNX-unilinker method (Hamilton et al., 1999) are also unsuitable for high-throughput marker development owing to labor-intensive cloning and screening steps. The advent of new-generation sequencing technologies such as sequencing by synthesis (Ronaghi et al., 1998) and ligation-mediated sequencing (Shendure et al., 2005) could therefore provide alternative methods for generating large data sets, minimizing effort, and decreasing costs.

Pyrosequencing is based on the real-time acquisition of DNA synthesis data via bioluminescence and is driven by four enzymes: Klenow DNA polymerase I, ATP sulfurylase, luciferase, and apyrase (Ronaghi et al., 1998; Ahmadian et al., 2006). This technology has been used in single-nucleotide polymorphism genotyping (Ahmadian et al., 2000) and expressed sequence tag sequencing (Galindo et al., 2010). Pyrosequencing has also been used to develop microsatellite markers for a number of fungal, insect, bird, reptile, and plant species (Abdelkrim et al., 2009; Allentoft et al., 2009; Santana et al., 2009; Castoe et al., 2010; Blanca et al., 2011). These studies have shown that pyrosequencing is an effective platform for the automation of certain analytical steps within a standard marker development protocol, making it a more time-efficient strategy.

In this study, pyrosequencing was used to generate data from a repeat-enriched genomic library. Primers for microsatellite loci were designed and further characterized. The data generated using pyrosequencing were also screened against National Center for Biotechnology Information (NCBI) databases to identify possible orthologs and gene associations. 


\section{MATERIAL AND METHODS}

\section{Sample collection and DNA extractions}

Sixteen H. midae samples were collected from wild fish at Saldanha Bay (west coast of South Africa). Genomic DNA was isolated from muscle tissue using a cetyltrimethylammonium bromide protocol (Saghai-Maroof et al., 1984).

\section{Genomic library construction}

The FIASCO method (Zane et al., 2002) was used to construct a repeat-enriched genomic library. A total of $250 \mathrm{ng} H$. midae DNA was digested with MseI (New England Biolabs) and ligated to $\mathrm{Mse}$ I adaptors. This sample was then selectively amplified and separately enriched with biotinylated (AC) ${ }_{12},(\text { GATC })_{6},(\mathrm{CAA})_{8}$, and (GTGC) 6 probes and recovered using streptavidin magnetic particles. These enriched particles were again selectively amplified using an MseI-specific primer mix.

\section{Pyrosequencing and primer design}

A final amount $(5 \mu \mathrm{g})$ of polymerase chain reaction (PCR) product was sequenced using the Roche 454 GS-FLX system at Inqaba Biotech (Pretoria, South Africa). Samples were prepared and analyzed according to the manufacturer protocol. Single reads were obtained and contiguous sequences were constructed using the Newbler version 1.1.03.24 software. All the contiguous sequences were trimmed of any adaptor sequences using the Find and Replace function of Microsoft Word. These sequences were then analyzed for length, GC content, and repeat motifs using the online software program BatchPrimer3 version 1 (You et al., 2008). The same software package was used to design primers for repeats containing contiguous sequences for which adequate flanking regions were available. To avoid primer redundancy, all contiguous sequences for which primers were designed were screened against a local Basic Local Alignment Search Tool (BLAST) database (created using BioEdit version 5.0.9; Hall, 1999), which contained all the microsatellite sequences generated thus far for $H$. midae.

\section{Genotyping}

All PCR applications were conducted in a Geneamp 2700 thermo cycler (Applied Biosystems; Johannesburg, South Africa) in $10-\mu \mathrm{L}$ reaction volumes containing $20 \mathrm{ng}$ DNA, $0.2 \mu \mathrm{M}$ of each primer, $200 \mu \mathrm{M}$ deoxyribonucleotide triphosphates, $0.1 \mathrm{U}$ 2 G Fast Taq polymerase (KAPA Biosystems; Cape Town, South Africa), 1X buffer B (KAPA Biosystems), and $2 \mathrm{mM} \mathrm{MgCl}_{2}$. A fast touchdown PCR program was used: an initial activation and denaturing step at $95^{\circ} \mathrm{C}$ for $2 \mathrm{~min}$, followed by 10 cycles of $1 \mathrm{~s}$ at $94^{\circ} \mathrm{C}$ and $5 \mathrm{~s}$ at $65^{\circ} \mathrm{C}$ and 30 cycles of $1 \mathrm{~s}$ at $94^{\circ} \mathrm{C}$ and $5 \mathrm{~s}$ at $55^{\circ} \mathrm{C}$. A final elongation step was performed at $72^{\circ} \mathrm{C}$ for $10 \mathrm{~s}$. PCR products were separated on a $3730 \mathrm{xl}$ DNA Analyzer (Applied Biosystems) and scored using GeneMapper version 4 (Applied Biosystems). 


\section{Statistical analyses and bioinformatics}

Sixteen Saldanha Bay samples were used to characterize the microsatellite loci. The number of alleles, observed and expected heterozygosities, and polymorphic information content (PIC) were calculated using CERVUS version 3.0.3 (Kalinowski et al., 2007). Deviations from Hardy-Weinberg equilibrium (Weir and Cockerham, 1984) were calculated using Genepop version 4 (Rousset, 2008). Sequential Bonferroni's correction was performed for multiple tests.

The bioinformatics protocol described by Farber and Medrano (2003) was used to search for possible homologous loci in related species. In brief, repeat motifs were masked using RepeatMasker (www.repeatmasker.org/cgi-bin/WEBRepeatMasker) to omit significant hits owing to repeat motif similarities. Masked sequences were then subjected to BLASTN and BLASTX in the nr-nucleotide and nr-protein databases of NCBI (http://blast.ncbi.nlm.nih. gov/Blast.cgi). Multiple alignments of query and subject sequences were used to determine the position of the microsatellite repeat within genes.

\section{RESULTS}

\section{Pyrosequencing and primer design}

A total of 11,271 single-sequence reads were generated covering $1.82 \mathrm{Mb}$ and assembled into 1067 contiguous sequences. One hundred and forty-one dinucleotide, 22 trinucleotide, 264 tetranucleotide, 20 pentanucleotide, and 15 hexanucleotide repeats were detected within 297 contiguous sequences. Primer pairs were successfully designed for 185 repeat-containing contiguous sequences using BatchPrimer3. Of these primer pairs, 27 were discarded because some of the individual primers were situated within repeat tracts, which may have caused difficulties in downstream applications such as PCR amplification and size calling of alleles. Another three sequences were discarded owing to similarity to previously isolated loci for which primers already existed. A total of 155 primer pairs were chosen for further analysis.

\section{Statistical analyses and bioinformatics}

The screening of the wild population revealed that 82 of 155 loci were polymorphic (Table 1). Ten of these loci had more than three alleles, indicating a duplication event within the same locus or possibly between loci. The number of observed alleles for the nonduplicated alleles ranged from 2 to 21 , expected heterozygosity ranged from 0.063 to 0.968 , observed heterozygosity ranged from 0.000 to 1.000 , and PIC ranged from 0.059 to 0.934 . Seventeen of the 82 microsatellite loci did not conform to Hardy-Weinberg equilibrium after sequential Bonferroni's correction $(\mathrm{P}<0.05)$.

Three loci gave statistically significant hits to sequences in the NCBI databases; however, all three had multiple significant hits to other haliotid genes or microsatellite loci. Hits to genes were always located in the $5^{\prime} / 3^{\prime}$-untranslated or intron regions (Table 2). Only one microsatellite locus, $H$ midPS1.588C, was strictly conserved between $H$. midae and $H$. $d$. hannai, taking into consideration the reverse complement. 


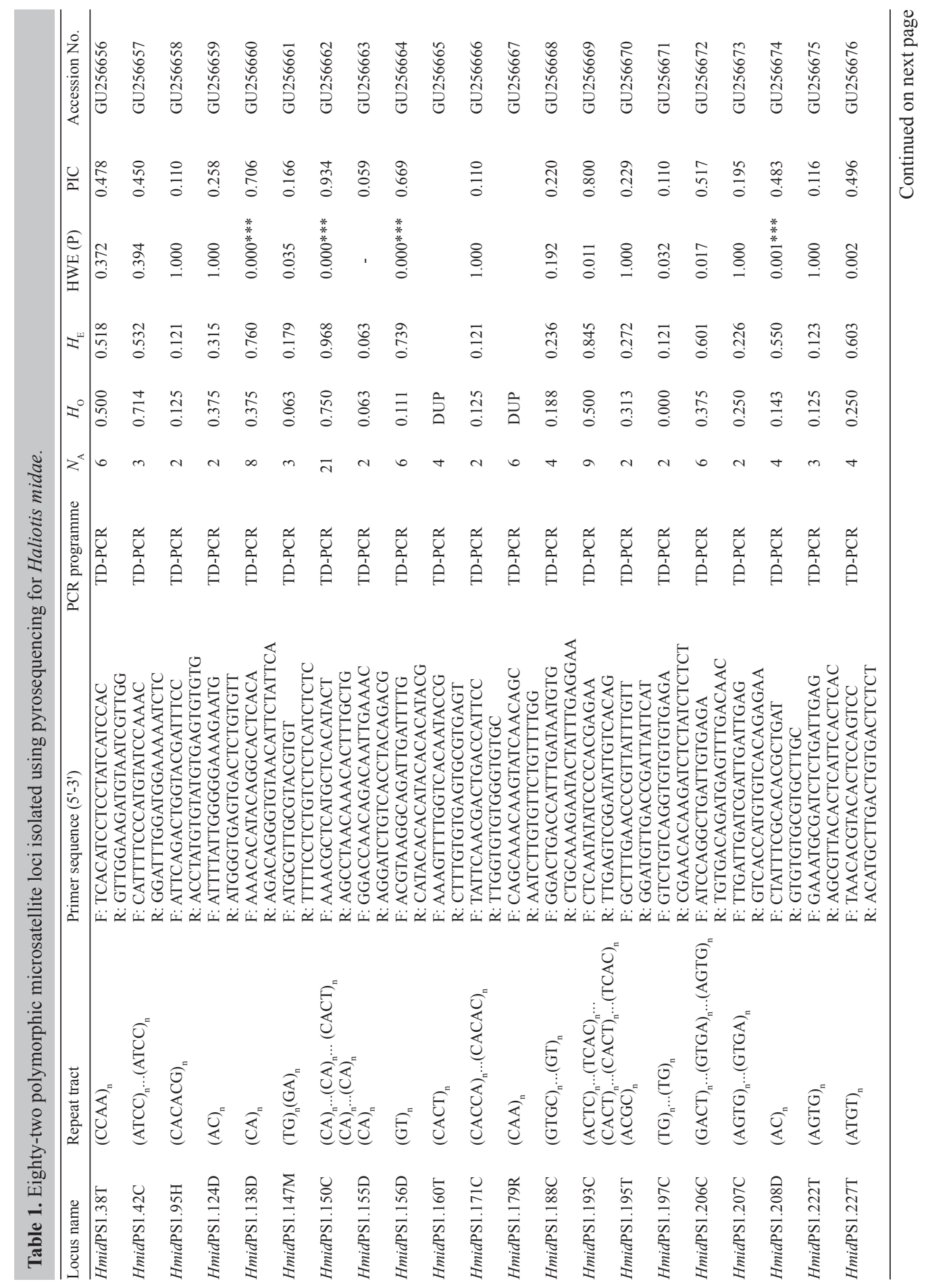




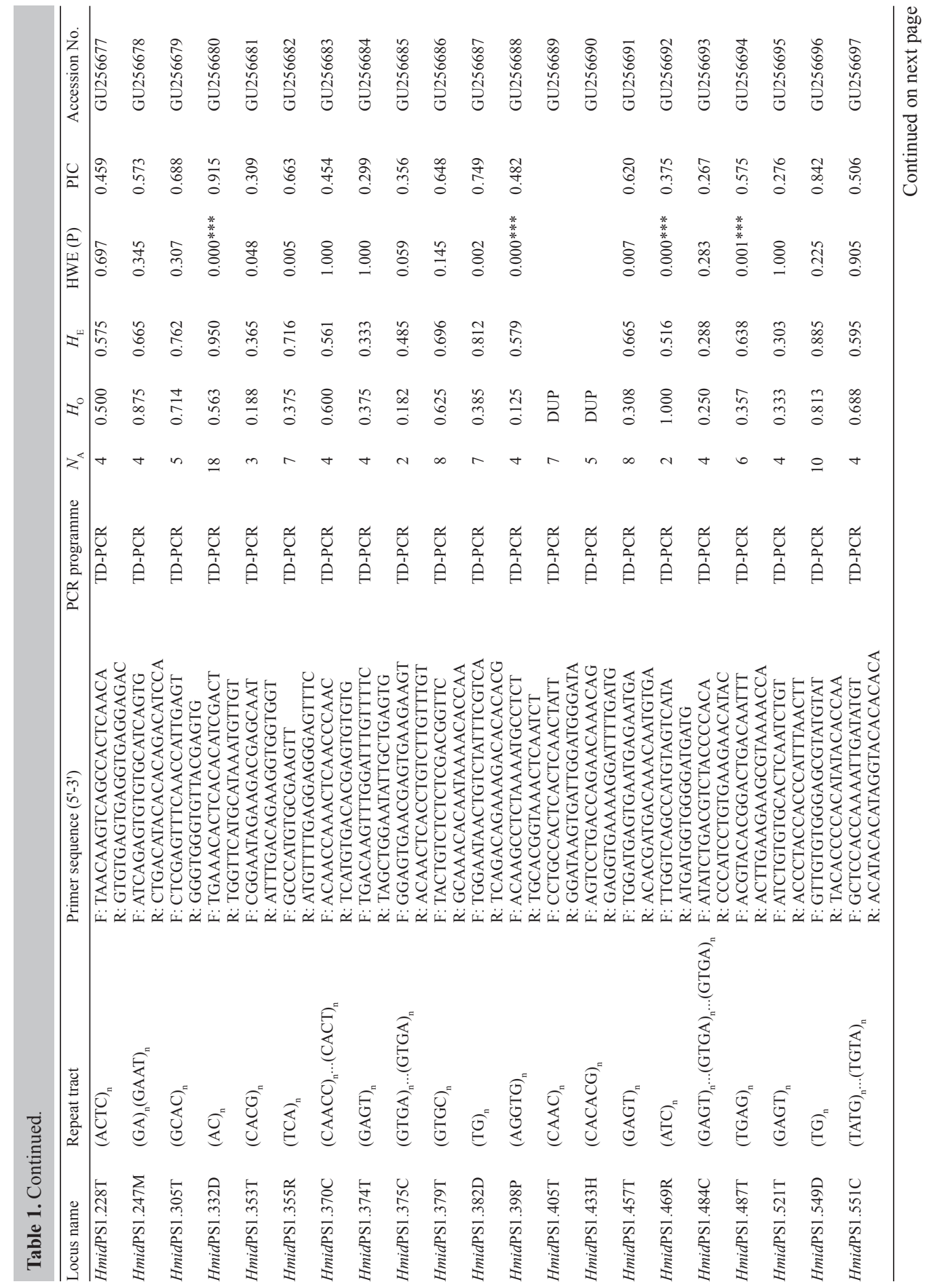




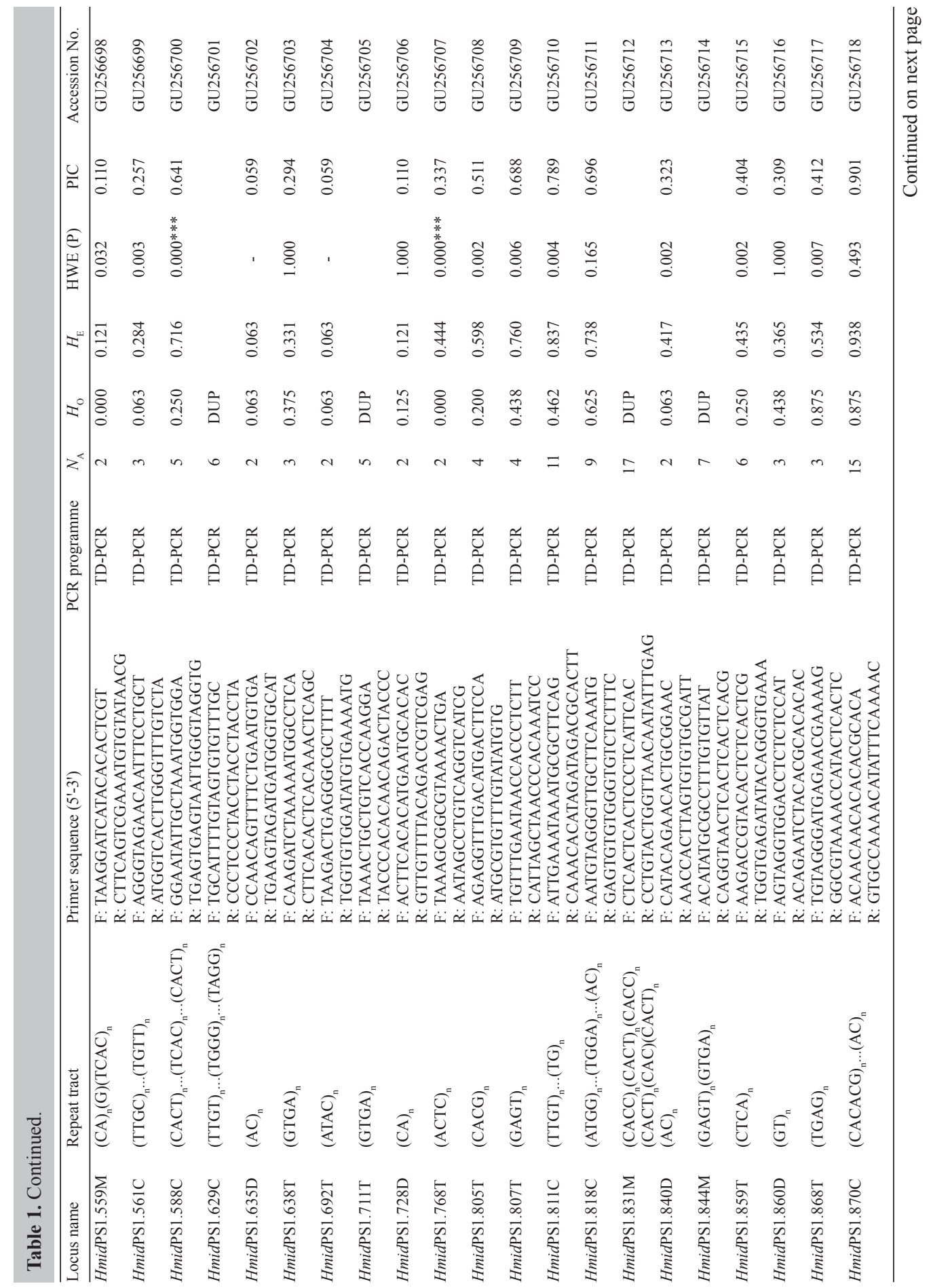




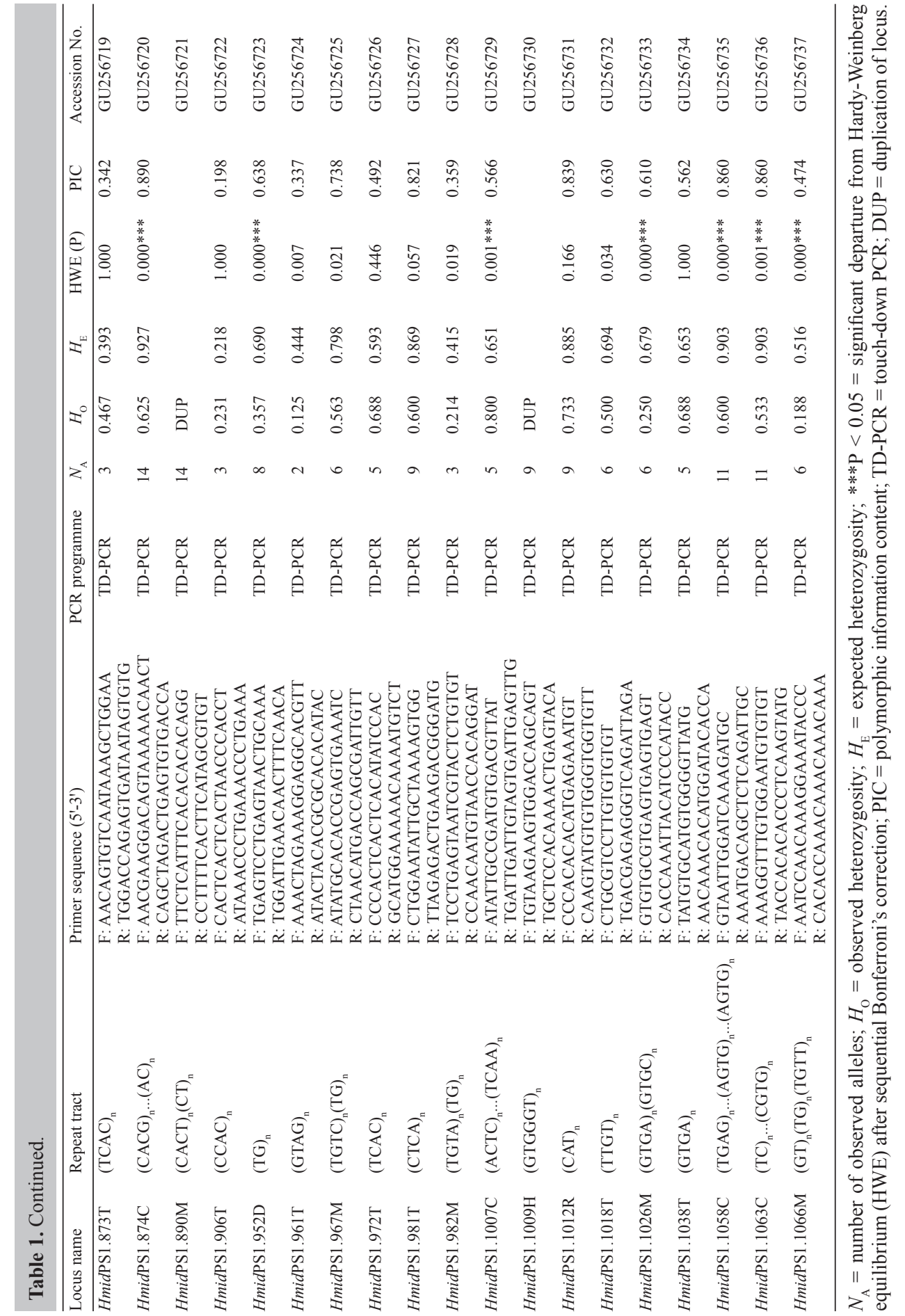




\begin{tabular}{|c|c|c|c|c|c|c|}
\hline \multirow[t]{2}{*}{ Locus name } & \multicolumn{3}{|c|}{ Microsatellite locus hits } & \multicolumn{3}{|c|}{ Gene hits } \\
\hline & Locus name (Accession No.) & E-value & Identities-value & Gene name (Accession No.) & E-value & Identities-value \\
\hline \multirow[t]{3}{*}{ HmidPS1.374T } & $\begin{array}{l}\text { H. d. hannai microsatellite } \\
(\text { AAAC) })_{\mathrm{n}} \text { (GU995824) }\end{array}$ & $5 e-09$ & $90 \%$ & $\begin{array}{l}\text { H. discus lysin } \\
\text { (FJ940391) }\end{array}$ & $2 \mathrm{e}-08$ & $87 \%$ \\
\hline & & & & $\begin{array}{l}\text { H. rufescens lysin } \\
\text { (AF076822) }\end{array}$ & $2 \mathrm{e}-08$ & $87 \%$ \\
\hline & & & & $\begin{array}{l}\text { H. corrugata lysin } \\
\text { (FJ940473.1) }\end{array}$ & $3 e-07$ & $88 \%$ \\
\hline \multirow[t]{3}{*}{ HmidPS1.588C } & $\begin{array}{l}\text { H. d. hannai microsatellite } \\
(\text { GAGT })_{\mathrm{n}}(\mathrm{AB} 177913)\end{array}$ & $8 \mathrm{e}-09$ & $78 \%$ & $\begin{array}{l}\text { H. rubra ATPase alpha-subunit } \\
\text { (AY043205) }\end{array}$ & $2 \mathrm{e}-07$ & $78 \%$ \\
\hline & $\begin{array}{l}\text { H. kamtschatkana microsatellite } \\
(\mathrm{GT})_{n}(\mathrm{AY} 013579)\end{array}$ & $3 e-05$ & $79 \%$ & $\begin{array}{l}\text { H. d. discus peroxiredoxin } \\
\text { (EF103356) }\end{array}$ & $3 e-05$ & $80 \%$ \\
\hline & $\begin{array}{l}\text { H. sieboldii microsatellite } \\
(\mathrm{CT})_{\mathrm{n}}(\mathrm{JF} 693957)\end{array}$ & $1 \mathrm{e}-10$ & $79 \%$ & & & \\
\hline \multirow[t]{2}{*}{ HmidPS1.1007C } & $\begin{array}{l}\text { H. rubra microsatellite } \\
(\mathrm{CA})_{\mathrm{n}}(\mathrm{AF} 194955)\end{array}$ & $7 e-08$ & $95 \%$ & $\begin{array}{l}\text { H. tuberculata hemocyanin } \\
\text { (AJ252741) }\end{array}$ & $7 e-05$ & $90 \%$ \\
\hline & $\begin{array}{l}\text { H. d. hannai microsatellite } \\
(\mathrm{CT})_{\mathrm{n}}(\mathrm{AB} 177931)\end{array}$ & $7 e-8$ & $95 \%$ & & & \\
\hline
\end{tabular}

\section{DISCUSSION}

A total of 82 microsatellite markers were developed for $H$. midae using the FIASCO method and the 454 pyrosequencing. The usefulness of these newly designed microsatellite markers for future applications such as population structure analysis, parentage assignments, and linkage mapping was assessed by calculating various parameters. Deviations from HardyWeinberg equilibrium (see Table 1) were mostly the result of heterozygote deficiency caused by the presence of null alleles (O'Connell and Wright, 1997), allele dropout, or scoring errors (Jones and Ardren, 2003). Two observations (HmidPS1.469R and HmidPS1.1007C) were explained by heterozygote excess. Although loci such as HmidPS1.469R and HmidPS1.1007C could be interesting candidates for studying selection processes in the life history of $H$. midae, they should be used with caution. The high PIC values obtained for many of the loci make them good candidates for parentage assignments and linkage mapping owing to a strong likelihood of being informative in both parent and offspring.

Amplification of more than the expected two alleles has previously been observed in H. midae (Slabbert et al., 2010) and H. rubra (Evans et al., 2001). The exact mechanisms underlying this occurrence are still unclear but could be explained by genome duplication, polyploidy, aneuploidy, or conserved microsatellite repeat tracts and flanking regions found in mobile elements (Hubert et al., 2000). A recent study by Rhode and Roodt-Wilding (2011) found that $21 \%$ of all known $H$. midae microsatellite loci are associated with characterized transposable elements, which play a role in locus duplication. This high association may therefore be the most likely explanation for duplications in abalone microsatellites.

Three loci were found to have orthologs in other haliotids. The lack of strict repeat motif conservation is expected taking into account the life cycle hypothesis of microsatellite evolution (Ellegren, 2004). These loci also had significant hits to haliotid genes. BLAST alignment analysis showed that the repeat motif was located in the untranslated region or introns. Furthermore, because individual loci are present across haliotid species and not necessarily in the same genes, these loci might form parts of gene regulatory elements (Li et al., 2004). Two of these markers (HmidPS1.588C and HmidPS1.1007C) deviated from Hardy-Weinberg 
expectations, which may indicate functional constraints and thus selective pressures. These loci are prime candidates for synteny mapping, QTL, and functional analysis.

The data generated using FIASCO and pyrosequencing 454 were accurate and adequate for the development and characterization of 82 polymorphic microsatellite markers. Pyrosequencing provides sequence information on all available DNA fragments present within an enriched library, in contrast to traditional cloning in which technical, time, and budget constraints cause the loss of significant information. The characterization of the newly designed markers showed that many of them would be useful for parentage and population studies. The additional markers will also contribute to the construction of a detailed linkage map.

\section{ACKNOWLEDGMENTS}

Research supported by the National Research Foundation of South Africa (The Innovation Fund) and a consortium of the following abalone hatcheries: Abagold (Pty) Ltd., Aquafarm (Pty) Ltd., HIK Abalone Farm (Pty) Ltd., Irvin and Johnson Abalone (I\&J) Ltd., and Roman Bay Sea Farm (Pty) Ltd. We thank Dr. Peizheng Wang for technical assistance, Arnold Vlok for assistance during sample collection, and Stellenbosch University for the use of facilities.

\section{REFERENCES}

Abdelkrim J, Robertson B, Stanton JA and Gemmell N (2009). Fast, cost-effective development of species-specific microsatellite markers by genomic sequencing. Biotechniques 46: 185-192.

Ahmadian A, Gharizadeh B, Gustafsson AC, Sterky F, et al. (2000). Single-nucleotide polymorphism analysis by pyrosequencing. Anal. Biochem. 280: 103-110.

Ahmadian A, Ehn M and Hober S (2006). Pyrosequencing: history, biochemistry and future. Clin. Chim. Acta 363: 83-94.

Allentoft M, Schuster SC, Holdaway R, Hale M, et al. (2009). Identification of microsatellites from an extinct moa species using high-throughput (454) sequence data. Biotechniques 46: 195-200.

Baranski M, Rourke M, Loughnan S, Austin C, et al. (2006). Isolation and characterization of 125 microsatellite DNA markers in the blacklip abalone, Haliotis rubra. Mol. Ecol. Notes 6: 740-746.

Bester AE, Slabbert R and D'Amato ME (2004). Isolation and characterization of microsatellite markers in the South African abalone (Haliotis midae). Mol. Ecol. Notes 4: 618-619.

Blanca J, Canizares J, Roig C, Ziarsolo P, et al. (2011). Transcriptome characterization and high throughput SSRs and SNPs discovery in Cucurbita pepo (Cucurbitaceae). BMC Genomics 12: 104.

Castoe TA, Poole AW, Gu W, Jason de Koning AP, et al. (2010). Rapid identification of thousands of copperhead snake (Agkistrodon contortrix) microsatellite loci from modest amounts of 454 shotgun genome sequence. Mol. Ecol. Resour. 10: 341-347.

Cook P and Britz PJ (1991). Perlemoen farming in South Africa. Mariculture Association of Southern Africa, Fishing Industry Research Institute, Cape Town.

DAFF (Department of Agriculture, Forestry and Fisheries) (2012). Aquaculture Annual Report 2011, South Africa.

Ellegren H (2004). Microsatellites: simple sequences with complex evolution. Nat. Rev. Genet. 5: 435-445.

Evans B, White RW and Elliott NG (2000). Characterization of microsatellite loci in the Australian Blacklip abalone (Haliotis rubra, Leach). Mol. Ecol. 9: 1183-1184.

Evans B, Conod N and Elliott NG (2001). Evaluation of microsatellite primer conservation in abalone. J. Shellfish Res. 20: $1065-1070$.

Farber CR and Medrano JF (2003). Putative in silico mapping of DNA sequences to livestock genome maps using SSLP flanking sequences. Anim. Genet. 34: 11-18.

Galindo J, Grahame JW and Butlin RK (2010). An EST-based genome scan using 454 sequencing in the marine snail Littorina saxatilis. J. Evol. Biol. 23: 2004-2016.

Gutiérrez-Gonzales JL, Cruz P, Del Rio-Portilla MA and Perez-Enriquez R (2007). Genetic structure of green abalone Haliotis fulgens population off Baja California, Mexico. J. Shellfish Res. 26: 839-846.

Hall TA (1999). BioEdit: a user-friendly biological sequence alignment editor and analysis program for Windows 95/98/ 
NT. Nucleic Acids Symp. Ser. 41: 95-98.

Hamilton MB, Pincus EL, Di FA and Fleischer RC (1999). Universal linker and ligation procedures for construction of genomic DNA libraries enriched for microsatellites. Biotechniques 27: 500-507.

Hubert S, English LJ, Landau BJ, Guo X, et al. (2000). Microsatellite analysis of trisomic families in the Pacific oyster, Crassostrea gigas, Thunberg. J. Shellfish Res. 19: 615.

Jones AG and Ardren WR (2003). Methods of parentage analysis in natural populations. Mol. Ecol. 12: 2511-2523.

Kalinowski ST, Taper ML and Marshall TC (2007). Revising how the computer program CERVUS accommodates genotyping error increases success in paternity assignment. Mol. Ecol. 16: 1099-1106.

Li Q and Akihiro K (2007). Sequence characterization of microsatellite DNA sequences in Pacific abalone (Haliotis discus hannai). J. Ocean Univ. Chin. 6: 47-52.

Li Q, Shu J, Yu R and Tian C (2007). Genetic variability of cultured populations of the Pacific abalone (Haliotis discus hannai Ino) in China based on microsatellites. Aquac. Res. 38: 981-990.

Li YC, Korol AB, Fahima T and Nevo E (2004). Microsatellites within genes: structure, function, and evolution. Mol. Biol. Evol. 21: 991-1007.

O’Connell M and Wright JM (1997). Microsatellite DNA in fishes. Rev. Fish. Biol. 7: 331-363.

Rhode C and Roodt-Wilding R (2011). Bioinformatic survey of Haliotis midae microsatellites reveals a non-random distribution of repeat motifs. Biol. Bull. 221: 147-154.

Ronaghi M, Uhlen M and Nyren P (1998). A sequencing method based on real-time pyrophosphate. Science 281: 363-365.

Rousset F (2008). Genepop'007: a complete re-implementation of the genepop software for Windows and Linux. Mol. Ecol. Resour. 8: 103-106.

Saghai-Maroof MA, Soliman KM, Jorgensen RA and Allard RW (1984). Ribosomal DNA spacer-length polymorphisms in barley: mendelian inheritance, chromosomal location, and population dynamics. Proc. Natl. Acad. Sci. U. S. A. 81: 8014-8018.

Santana QC, Coetzee MPA, Steenkamp ET, Mlonyeni OX, et al. (2009). Microsatellite discovery by deep sequencing of enriched genomic libraries. Biotechniques 46: 217-223.

Selvamani MJP, Degnan SM, Paetkau D and Degnan BM (2000). Highly polymorphic microsatellite loci in the Heron Reef population of the tropical abalone Haliotis asinina. Mol. Ecol. 9: 1184-1186.

Shendure J, Porreca GJ, Reppas NB, Lin X, et al. (2005). Accurate multiplex polony sequencing of an evolved bacterial genome. Science 309: 1728-1732.

Shi Y, Guo X, Gu Z, Wang A, et al. (2010). Preliminary genetic linkage map of the abalone Haliotis diversicolor Reeve. Chin. J. Oceanol. Limn. 28: 549-557.

Slabbert R, Ruivo NR, Van den Berg NC, Lizamore DL, et al. (2008). Isolation and characterization of 63 microsatellite loci for the abalone, Haliotis midae. J. World Aquacult. Soc. 39: 429-435.

Slabbert R, Bester AE and D'Amato ME (2009a). Analyses of genetic diversity and parentage within a South African hatchery of the abalone Haliotis midae Linnaeus using microsatellite markers. J. Shellfish Res. 28: 369-375.

Slabbert R, Roux A, Van der Merwe M, Watson L, et al. (2009b). Genetic Enhancement in the South African Abalone (Haliotis midae): Current Status. In: Book of Abstracts of the 10th International Symposium on Genetics in Aquaculture, Bangkok, 22-26.

Slabbert R, Hepple J, Venter A, Nel S, et al. (2010). Isolation and segregation of 44 microsatellite loci in the South African abalone Haliotis midae L. Anim. Genet. 41: 332-333.

Weir BS and Cockerham CC (1984). Estimating F-statistics for the analysis of population structure. Evolution 38: 13581370.

You FM, Huo N, Gu YQ, Luo MC, et al. (2008). BatchPrimer3: a high throughput web application for PCR and sequencing primer design. BMC Bioinformatics 9: 253.

Zane L, Bargelloni L and Patarnello T (2002). Strategies for microsatellite isolation: a review. Mol. Ecol. 11: 1-16. 